\title{
Penerapan Model Pembelajaran Kooperatif Tipe Team Assisted Individualization (TAI) untuk Meningkatkan Aktivitas dan Hasil Belajar Siswa pada Mata Pelajaran Ekonomi di SMA Negeri 2 Denpasar
}

\author{
Komang Windhi Indriyani ${ }^{*}$, I Nyoman Sujana²
}

1,2 Universitas Pendidikan Ganesha, Singaraja - Indonesia

\section{A R T I C L E I N F O \\ Article history: \\ Received January, 42021 Received in revised form November, 232021 \\ Accepted November, 24 2021 \\ Available online December,} 252021

\section{Kata Kunci:}

Aktivitas belajar, hasil belajar siswa, model pembelajaran kooperatif, model pembelajaran team assisted individualization (TAI).

Keywords: Cooperative learning, learning activities, model of learning team assisted individualization, student incurina

\begin{abstract}
A B S T R A K
Tujuan studi ini mengetahui, (1) peningkatan aktivitas belajar siswa dalam pelajaran ekonomi melalui penerapan model kooperatif tipe team assisted individualization (2) peningkatan hasil belajar siswa pada mata pelajaran ekonomi melalui penerapan model pembelajaran team assisted individualization. Studi ini merupakan PTK melalui 2 siklus. Subyek studi ini yaitu 45 orang siswa kelas X IPA 4 SMA Negeri 2 Denpasar. Obyek studi ini yakni aktivitas dan hasil belajar siswa dibidang pembelajaran ekonomi melalui pengimplementasian model pembelajaran Team Assisted Individualization. Studi ini menggunakan data kuantitatif yang bersumber dari data primer. Pengumpulan data dilakukan melalui metode observasi dan tes. Deskriptif kuantitatif digunakan sebagai teknik analisis data. Hasil studi menunjukkan bahwa, (1) adanya peningkatan aktivitas belajar siswa melalui penerapan model TAI, selama siklus I mendapatkan rata-rata 6,75 berkategori cukup aktif kemudian di siklus II meningkat menjadi 8,85 berkategori aktif, dan (2) Penggunaan model pembelajaran TAI bisa memperbaiki hasil belajar siswa, di siklus I didapat rerata 67,11 berkategori cukup dan selama siklus II bertambah menjadi 80,11 pada kategori baik.
\end{abstract}

\section{A B S T R A C T}

The study aimed to find out (1) the improvement of student's learning activity in economic subjects by implementing team assisted individualization model. (2) the improvement of student's learning outcomes by implementing team assisted individualization model. This research was CAR that was done in 2 cycles. The subject was 45 tenth graders in SMA Negeri 2 Denpasar. The objects of the study were students' learning activities and learning outcomes. The study was quantitative research where the data source used primary data. The data was collected through observation and test. The results showed that, (1) TAI model increase student's learning activities, the average in the first cycle of 6.75 with active category, then in the second cycle it increased to 8,85 in the active category. (2) The implementation of the TAI improves student's learning outcomes, with the average of 67.11 in the sufficient category, then in the second cycle it increased to 80,11 with a good category.

\footnotetext{
* Corresponding author.

E-mail : windhiindriyani06@gmail.com (Komang Windhi Indriyani)
} 


\section{Pendahuluan}

Pendidikan adalah suatu usaha pemerintah dalam menciptakan dan memelihara Sumber Daya Manusia (SDM), dengan bermacam aktivitas pembelajaran di setiap level pendidikan dari level dasar, menengah sampai perguruan tinggi. Pendidikan formal bertujuan agar siswa mampu membangun pengetahuan, keterampilan maupun sikap yang menjadi suatu bentuk perubahan perilaku dan hasil belajar (Sutiari, 2019).

Pembelajaran ekonomi ialah suatu pembelajaran dinamis dan paling dekat dengan kegiatan seharihari siswa. Selain itu, pelajaran ekonomi memiliki tujuan agar siswa dapat membangun perilaku bijak, rasional, serta bertanggung jawab melalui penguasaan pengetahuan dan keterampilan ilmu ekonomi yang berguna untuk individu, masyarakat dan negara. Pemahaman konsep ekonomi pada pembelajaran Ekonomi sangatlah penting agar siswa mampu mencapai hasil maksimal atau sesuai Kriteria Ketuntasan Minimum (KKM) di SMA Negeri 2 Denpasar.

(Sudjana, 2016) menyatakan hasil belajar ialah kompetensi yang dikuasai seorang siswa sesudah mendapatkan pengalaman belajar. Hasil belajar, khususnya pada jenjang SMA terlepas dari proses pembelajaran yang dialami siswa itu sendiri. Proses pembelajaran akan berjalan dengan kondusif dan bermakna jika siswa mampu untuk belajar dengan aktif dalam hubungan pembelajaran antara siswa terhadap guru dan juga sebaliknya. Korelasi antara siswa dengan guru, siswa dengan teman sebaya, sangat diperlukan saat proses belajar mengajar berlangsung.

Selama proses pembelajaran di kelas X IPA 4, guru memanfaatkan model pembelajaran CTL (Contextual Teaching and Learning) berbantuan media powerpoint. Proses belajar CTL berbantuan media powerpoint, tersebut memperlihatkan kecenderungan proses pembelajaran berpusat pada guru. Hal ini mempengaruhi lemahnya partisipasi siswa selama pembelajaran. Partisipasi siswa sangatlah krusial dalam aktivitas belajar sebab tanpa adanya aktivitas belajar maka dapat menyebabkan rendahnya hasil belajar siswa.

Siswa kelas X IPA 4 di SMA Negeri 2 Denpasar masih belum mampu meraih hasil belajar maksimal sesuai KKM yang diberlakukan. Siswa yang belum mendapat nilai KKM sejumlah 30 siswa dan siswa yang telah mencapai KKM sejumlah 15 orang dikelas X IPA 4 SMA Negeri 2 Denpasar. Presentase siswa yang masih tidak mendapatkan nilai KKM sebesar 66.67\%, sedangkan siswa yang meperoleh nilai KKM sebesar 33,33\%. Dari hasil wawancara dengan sejumlah siswa kelas X IPA 4 yaitu, siswa merasa materi yang diajarkan oleh guru sangat cepat membuat mereka tidak bisa mengikuti proses pembelajaran dengan baik. Solusi atau pemecahan masalah di atas adalah dengan memperbaiki proses pembelajaran di dalam kelas melalui pengimplementasian model pembelajaran Team Assisted Individualization (TAI) dalam bidang ilmu ekonomi.

Model pembelajaran Team Assisted Individualization (TAI) dikembangkan oleh Robert Slavin di Johns Hopkins University bersama Nancy Madden (Sharan, 2014). Menurut (Slavin, 2015), Team Assisted Individualization ialah model pembelajaran yang menggunakan kelompok heterogen dari sejumlah siswa yakni setiap kelompoknya 4-6 orang siswa, yang bekerja bersama guna menyelesaikan permasalahan yang diberikan. Pemberian bantuan setiap individual dari siswa pintar bagi peserta didik yang memerlukan di masing-masing kelompok juga dibutuhkan pada proses pembelajaran ini. Model (TAI) ini bisa memaksimalkan pencapaian belajar siswa karena proses pembelajaran dengan cara berkelompok dibantu dengan adanya tutor sebaya dapat membuat siswa dapat mengerti atau mengingat materi yang diberikan dengan baik dan akan diingat oleh siswa dalam jangka waktu yang panjang. Hal ini, lebih efektif dari pada materi tersebut diberikan secara langsung oleh guru dengan cara ceramah atau bercerita panjang lebar di depan kelas yang menimbulkan kebosanan pada siswa dan cepat mengantuk. Penerapan model pembelajaran TAI ini membuat kegiatan pembelajaran lebih optimal karena, dengan menerapkan model pembelajaran ini siswa diharuskan belajar secara berkelompok agar mampu memecahkan masalah dari guru.

Berdasarkan penelitian oleh (Sugiantoro \& Achmadi Hasyim, 2019), terdapat peningkatan aktivitas belajar siswa sesudah mengimplementasikan model TAI. Penelitian lain dilakukan oleh (Ariani, 2017) menunjukkan bahwa ada dampak model pembelajaran team assisted individualization pada pencapaian belajar fisika siswa. Hasil studi yang dilaksanakan (Sutiari, 2019) juga membuktikan ada peningkatan aktivitas dan prestasi belajar siswa dalam pelajaran tata graha setelah penerapan model team assisted individualization (TAI). Merujuk pada penelitian tersebut, maka untuk mengatasi permasalahan rendahnya aktivitas dan hasil belajar siswa kelas X IPA 4 dalam pelajaran ekonomi di SMA Negeri 2 Denpasar, model kooperatif TAI memungkinkan diimplementasikan.

Berdasarkan pemaparan ini, maka peneliti tertarik meneliti Penelitian Tindakan Kelas (PTK) berjudul "Penerapan Model Pembelajaran Kooperatif Tipe Team Assisted Individualization (TAI) untuk Meningkatkan Aktivitas dan Hasil Belajar Siswa pada Mata Pelajaran Ekonomi di SMA Negeri 2 Denpasar." 
Studi ini bertujuan: (1) untuk mengetahui peningkatan aktivitas belajar siswa pada mata pelajaran ekonomi melalui penggunaan model pembelajaran TAI, (2) untuk mengetahui peningkatan hasil belajar siswa dalam mata pelajaran ekonomi melalui penggunaan model pembelajaran TAI.

\section{Kajian Pustaka}

\section{Model Pembelajaran Kooperatif}

Menurut (Isjoni, 2019) mendefinisikan, "model pembelajaran kooperatif adalah aktivitas belajar didalam tim kecil yang beranggotakan maksimal 6 anggota yang dirancang guna membangun keaktifan siswa dengan cara mandiri dan diskusi kelompok agar mencapai tujuan bersama". Pembelajaran kooperatif disempurnakan guna meraih pencapaian belajar antara lain prestasi akademik, toleransi, mampu menghargai keragaman serta mengembangkan kemampuan social (Suprijono, 2013).

Pembelajaran kooperatif berhubungan dengan metode belajar dimana siswa dibagi menjadi tim kecil untuk saling membantu, diskusi dan memberikan pendapat guna melatih ilmu yang diketahuinya serta mengurangi perbedaan pemahaman setiap individual (Slavin, 2015). Sedangkan menurut (Sharan, 2014), "pembelajaran kooperatif merupakan suatu model pembelajaran dimana siswa belajar dan bekerja didalam kelompok kecil dengan 4-6 siswa".

\section{Model Pembelajaran Kooperatif Tipe Team Assisted Individualization (TAI)}

Seperti penjelasan (Slavin, 2015) model pembelajaran kooperatif tipe Team Assisted Individualization (TAI) ialah model pembelajaran yang mengkombinasikan pembelajaran individual melalui belajar kelompok, yang mengarahkan siswa belajar dalam tim guna menyelesaikan masalah individual setiap keompok serta saling menyalurkan motivasi sehingga pendidik memiliki kesempatan untuk terbebas dari pengajaran langsung pada tim kecil siswa yang bersifat homogen. Sedangkan (Sharan, 2014) menyatakan, model pembelajaran TAI menjadi suatu model pengajaran yang dapat melibatkan siswa berpartisipasi pada kelompoknya melalui pembelajaran individual.

Berbeda dengan tipe model pembelajaran kooperatif lainnya, Team Assisted Individualization terdiri atas delapan unsur yang sangat berangkaian satu sama lain (Slavin, 2015) yaitu teams, placement test, teaching group, student creative, team study, whole class units, fact test, team score dan team recognition.

Model pembelajaran TAI mempunyai langkah atau sintak pembelajaran untuk diimplemetasikan dikelas menurut (Ariani, 2017)sebagai berikut.

1) Langkah pertama yaitu placement test, dimana tahap ini guru mengadakan tes awal (pre-tes) pada siswa yang berfungsi guna mencari kelemahan dan kelebihan siswa pada bidang yang dimiliki siswa.

2) Setelah melakukan pre-test langkah kedua yaitu teams, pada langkah ini guru menyusun tim kecil dengan jumlah 4-5 siswa heterogen dilihat dari hasil pre-test masing-masing siswa.

3) Langkah ketiga teaching group dilakukan setelah guru membentuk siswa dalam kelompok, pada langkah ini guru menyediakan materi dengan ringkas sebelum tugas berkolompok disampaikan pada siswa.

4) Langkah keempat yaitu student creative yaitu, guru menegaskan serta menyampaikan pengertian pada siswa bahwa kesuksesan individu keberhasilan setiap individu ditetapkan atas kesuksesan setiap kelompok masing-masing.

5) Langkah kelima yaitu team study, siswa belajar dengan tim mereka dengan menyelesaikan soal dari guru disetiap kelompok. Guru menyediakan bantuan individual pada masing-masing siswa, dibantu oleh siswa dengan kemampuan akademis yang baik di tiap tim dan bertugas sebagai tutor sebaya.

6) Langkah keenam yaitu whole class units, ditahap ini setiap wakil kelompok menyampaikan hasil diskusi mereka, sedangkan kelompok laiinya menaggapi dengan berbagai pertanyaan serta pada tahap ini guru mengevaluasi hasil diskusi dan menyempurnakan jawaban dari siswa.

7) Langkah ketujuh yaitu fact test, pada tahap ini guru melaksanakan post-tes dan peserta didil mengerjakan secara mandiri.

8) Langkah kedelapan yaitu team score dan team recognition merupakan langkah terakhir, dimana guru mengumumkan nilai setiap tim pada satu siklus serta memberikan penghargaan pada kelompok yang paling baik dan hebat.

\section{Aktivitas Belajar}

Menurut (Slameto, 2015) mendefinisikan "belajar merupakan usaha individu guna mencapai transisi sikap menjadi lebih baik dari pengalamannya sendiri, disaat berinteraksi dengan lingkungannya". Sedangkan definisi belajar secara psikologis yakni proses berubahnya perilaku akibat dari hubungan dengan lingkungan saat memenuhi kebutuhan hidup. Transisi ini akan berlangsung pada seluruh bagian perilaku seseorang. 
Aktivitas menurut (Nasution, 2017) mendefinisikan "aktivitas adalah kegiatan atau keaktifan seseorang baik itu secara rohani maupun jasmani yang kedua-duanya harus dihubungkan satu sama lain”. Sedangkan menurut (Sardiman, 2016) aktivitas adalah suatu prinsip yang fundamental disetiap kegiatan pembelajaran di dalam kelas.

(Hamalik, 2015) mendefinisikan aktivitas belajar sebagai aktivitas yang dilaksanakan siswa dalam proses belajar. Sedangkan menurut (Sardiman, 2016) mengemukakan, "aktivitas belajar ialah serangkaian aktivitas fisik serta mental yang saling berhubungan agar terciptanya pembelajaran yang maksimal melalui partisipasi siswa dalap proses pembelaajran dalam meningkatkan kemampuan yang dimilikinya".

\section{Hasil Belajar}

Hasil belajar bagian terpenting selama kegiatan belajar dikelas. Menurut (Sudjana, 2016) mendefinisikan, "hasil belajar yaitu keahlian seorang siswa, setelah mengalami proses pembelajaran". Sedangkan (Dimyati dan Mudjiono, 2015) menyatakan, "hasil belajar sebagai hasil proses interaksi dalam pembelajaran".

Selain itu, hasil belajar menurut (Purwanto, 2017) ialah berubahnya suatu sikap yang berlangsung sesudah mengikuti pembelajaran berdasarkan tujuan pendidikan yakni kognitif, afektif dan psikomotorik.

Faktor internal maupun eksternal merupakan faktor yang memberikan pengaruh pada hasil belajar. Faktor internal disini yaitu jasmani, fisikologis dan kelelahan (Slameto, 2015).

\section{Metode}

Studi ini memanfaatkan jenis penelitian tindakan kelas. Menurut (Sanjaya, 2014) penelitian tindakan kelas yaitu suatu usaha dalam proses belajar mengajar untuk menyelesaikan masalah pembelajaran didalam kelas, melalui beberapa tindakan yang terorganisasi pada kondisi nyata.

Rancangan studi ini terdiri atas 2 siklus dimana ada empat tahapan disetiap siklus yakni perencanaan tindakan, pelaksanaan, observasi serta refleksi (Trianto, 2012).

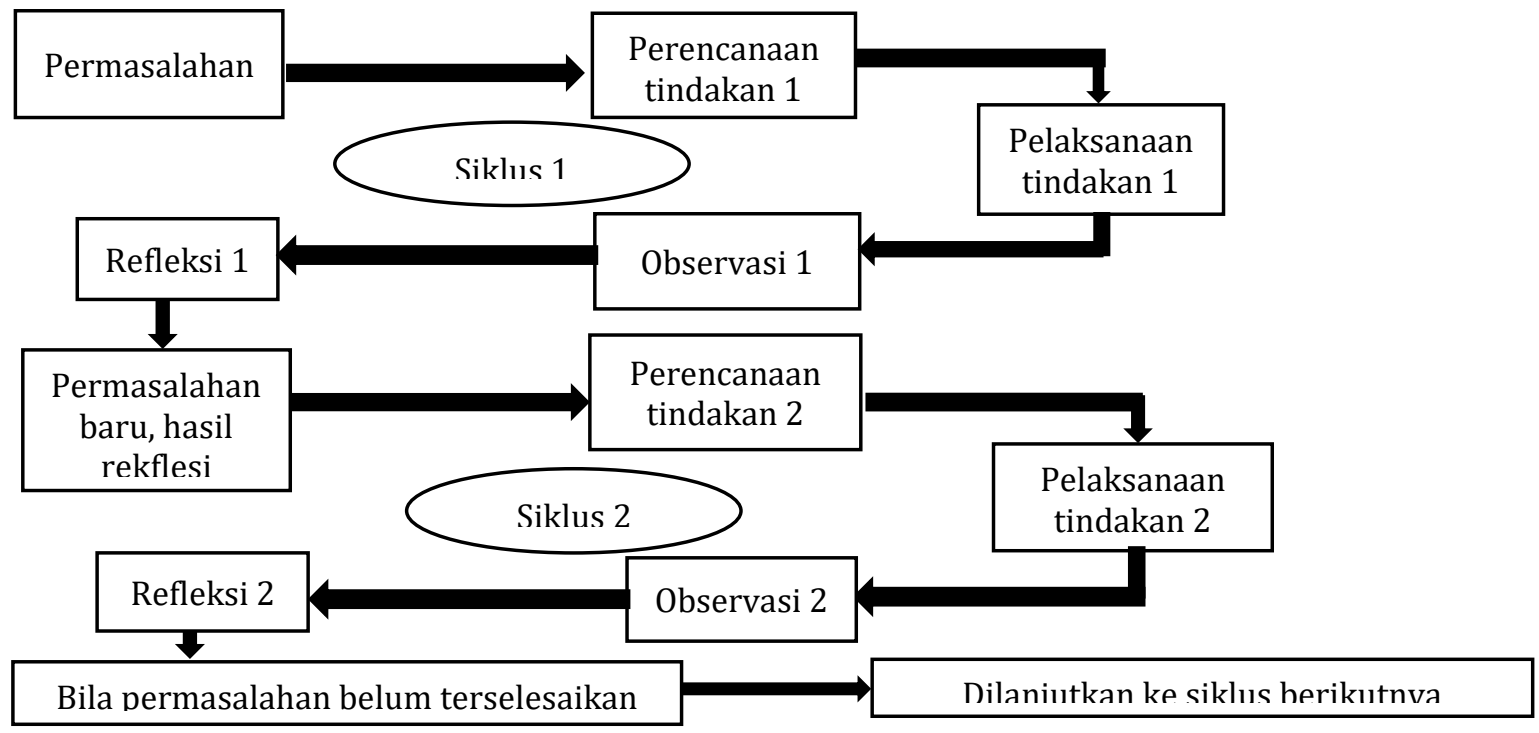

Gambar 1. Siklus Kegiatan PTK

Subjek studi ini yakni 45 siswa kelas X IPA 4 SMA Negeri 2 Denpasar. Obyek studi ini yaitu (1) aktivitas siswa serta (2) hasil belajar siswa selama pembelajaran ekonomi melalui pengimplementasian model Team Assisted Individualization.

Instrumen pengumpulan data pada studi ini yaitu observasi dan tes. Aktivitas belajar siswa dikumpulkan melalui metode observasi dengan penggunaan lembar observasi. Hasil belajar siswa diambil dengan metode tes ditiap akhir siklus.

Studi ini dianalisis dengan teknis deskriptif kuantitatif. Data aktivitas dicatat serta diamati dalam lembar observasi, selanjutnya dianalisis secara deskriptif kuantitatif (Yuliantari, 2016).

Data aktivitas belajar siswa diobservasi dan ditulis dalam lembar observasi. Kriteria yang digunakan dalan menggolongkan aktivitas belajar siswa dibuat sesuai nilai rerata aktivitas belajar siswa secara klasikal (X), Mean ideal (MI), serta Standar Devisiasi Ideal (SDI) menurut (Koyan, 2012). 


$$
\begin{array}{ll}
\text { MI } & =\frac{1}{2}(\text { skor terting gi idela }+ \text { skor terendah ideal }) \\
\text { SDI } & =\frac{1}{6}(\text { skor terting gi idela }+ \text { skor terendah ideal })
\end{array}
$$

Keterangan MI = Angka rerata ideal, SDI= Standar Deviasi Ideal

Dalam mengkategorikan skor aktivitas belajar peserta didik, menggunakan kriteria penggolongan aktivitas belajar secara klasikal.

Tabel 1. Pedoman Penggolongan Aktivitas Belajar Siswa.

\begin{tabular}{lll}
\hline No & \multicolumn{1}{c}{ Kriteria } & \multicolumn{1}{c}{ Kategori } \\
\hline 1. & $\mathrm{X} \geq 11,25$ & Sangat aktif \\
2. & $8,75 \leq \mathrm{X}<11,25$ & Aktif \\
3. & $6,25 \leq \mathrm{X}<8,75$ & Cukup aktif \\
4. & $3,75 \leq \mathrm{X}<6,25$ & Kurang aktif \\
5. & $\mathrm{X}<3,75$ & Sangat kurang aktif \\
\hline
\end{tabular}

(Sumber: Koyan, 2012)

Setelah data aktivitas belajar yang telah terkumpul tahap selanjut andalah menentukan rata-rata persentase aktivitas melalui formula sebagia berikut:

$\bar{X}=\frac{\sum X}{n} \times 100 \%$

Keterangan: $\bar{X}$ = nilai rata-rata presentase aktivitas belajar siswa, $\sum X=$ jumlah total nilai presentase aktivitas belajar siswa per orang, $\mathrm{n}=$ jumlah siswa.

(Koyan, 2012)

Data hasil belajar siswa didapatkan setelah pengimplementasian model pembelajaran Team Assisted Individualization dapat dihitung melalui skor atau rerata kelas $(\bar{X})$ menggunakan formula berikut. $\bar{X}=\frac{\Sigma X}{N}$

Keterangan: $\bar{X}=$ Nilai rata-rata, $\sum X=$ jumlah nilai seluruh siswa, $N=$ jumlah siswa (Sudjana, 2016)

Hasil belajar siswa digolongkan baik jika berada di kategori baik yang didapat sesuai panduan konversi nilai yang digunakan SMA Negeri 2 Denpasar.

Tabel 2. Pedoman Konversi Skor Hasil Belajar Siswa

\section{Hasil dan pembahasan}

(sumber: Pedoman penilaian SMA Negeri 2 Denpasar)

\begin{tabular}{cc}
\hline Skor & Kategori \\
\hline $85-100$ & Sangat baik \\
$75-84$ & Baik \\
$65-74$ & Cukup \\
$41-64$ & Kurang \\
$0-40$ & Sangat kurang \\
\hline \multicolumn{2}{c}{ Pedoman penilaian SMA Negeri 2 }
\end{tabular}

\section{Aktivitas Belajar Siklus I.}

Dari hasil pengumpulan data dan analisis siklus 1, diperoleh hasil aktivitas siswa. Aktivitas belajar siswa bisa ditunjukkan di Tabel 3.

Tabel 3. Data Aktivitas Belajar Siswa Siklus I

\begin{tabular}{lcccc}
\hline \multirow{2}{*}{ Kategori } & \multicolumn{4}{c}{ Sebaran Aktivitas Belajar Siswa } \\
\cline { 2 - 5 } & \multicolumn{2}{c}{ Pertemuan Pertama } & \multicolumn{2}{c}{ Pertemuan Kedua } \\
& Jumlah Siswa & Presentase & Jumlah & Presentase \\
& & & 3 & \\
\hline Sangat Aktif & 1 & $2,22 \%$ & 7 & $15,67 \%$ \\
Aktif & 6 & $13,33 \%$ & 20 & $44,44 \%$ \\
Cukup Aktif & 15 & $33.34 \%$ & 13 & $28,89 \%$ \\
Kurang Aktif & 16 & $35,55 \%$ & 2 & $4.45 \%$ \\
Sangat Kurang Aktif & 7 & $15,56 \%$ & 45 & $100,00 \%$ \\
\hline Jumlah & 45 & $100,00 \%$ & & \\
\hline
\end{tabular}


Berdasarkan Tabel 3 diatas, jumlah siswa yang masih belum memenuhi kategori aktif dan sangat aktif masih kurang walaupun pada pertemuan kedua sudah terjadi peningkatan yang tidak terlalu signifikan.

Berikut adalah bentuk grafik persentase aktivitas siswa dalam pertemuan I dan II. Persentase aktivitas belajar siswa dapat ditunjukkan dalam gambar 2 .

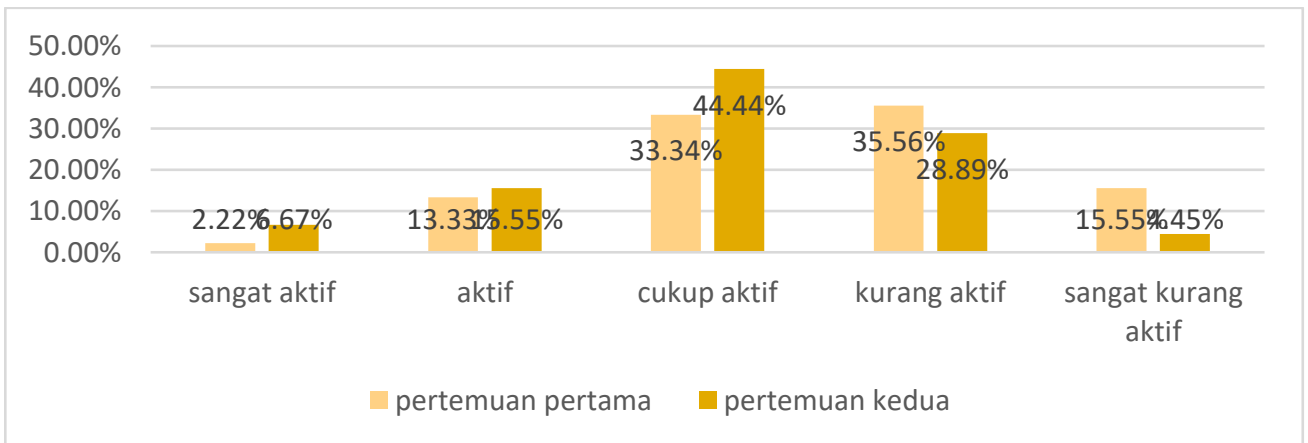

Gambar 2. Diagram Persentase Sebaran Aktivitas Belajar Siswa Siklus I.

Berdasarkan gambar diagram 2 menunjukkan presentase sebaran aktivitas belajar siswa di siklus I, dimana kategori sangat aktif, kategori aktif dan kategori cukup aktif persentase aktivitas belajar meningkat di pertemuan kedua. Sedangkan di kategori kurang aktif ataupun sangat kurang aktif mengalami penurunan di pertemuan kedua.

\section{Hasil Belajar Siswa Siklus I}

Mengacu pada hasil penelitian dan analisis hasil belajar siswa, data hasil belajar di siklus I dapat dilihat dari Tabel 4.

Tabel 4. Data Hasil Belajar Siswa Siklus I.

\begin{tabular}{|c|c|c|c|c|}
\hline No. & Rentangan Nilai & Kategori Nilai & Jumlah Siswa & Persentase \\
\hline 1. & $85-100$ & Sangat Baik & 3 & $6,67 \%$ \\
\hline 2. & $75-84$ & Baik & 17 & $37,78 \%$ \\
\hline 3. & $65-74$ & Cukup & 11 & $24,44 \%$ \\
\hline 4. & $41-64$ & Kurang & 11 & $24,44 \%$ \\
\hline 5. & $0-40$ & Sangat Kurang & 3 & $6,67 \%$ \\
\hline \multicolumn{3}{|c|}{ Total } & 45 & $100,00 \%$ \\
\hline
\end{tabular}

Sumber: (data diolah peneliti)

Tabel 4 diatas menunjukkan jumlah siswa dengan kategori sesuai KKM yang sekolah tetapkan masih sedikit. Hasil belajar siswa berdasarkan (KKM) yakni 75, maka bisa disimpulkan banyaknya siswa dengan nilai melebihi KKM di siklus I. Sebaran ketuntasan hasil belajar ini ditunjukkan pada Tabel 5.

Tabel 5. Sebaran Ketuntasan Hasil Belajar Siswa Pada Siklus I.

\begin{tabular}{ccc}
\hline Keterangan & Jumlah Siswa & Presentase \\
\hline Tuntas & 20 & $44,44 \%$ \\
Tidak Tuntas & 25 & $55,56 \%$ \\
\hline Jumlah & 45 & $100,00 \%$ \\
\hline Sumber: (data diolah peneliti) &
\end{tabular}

Dari tabel 5 ditunjukkan, sebaran ketuntasan hasil belajar siswa mata pelajaran ekonomi pada siklus I. Banyak siswa dengan nilai diatas KKM sejumlah 20 orang dengan presentase sebanyak $(44,44 \%)$ dan siswa dengan nilai dibawah KKM sejumlah 25 orang dengan besar presentase $(55,56 \%)$.

Berikut adalah bentuk grafik sebaran ketuntasan belajar siswa diakhir siklus I. Sebaran ketuntasan hasil belajar diakhir siklus I bisa diunjukkan dalam Gambar 3. 


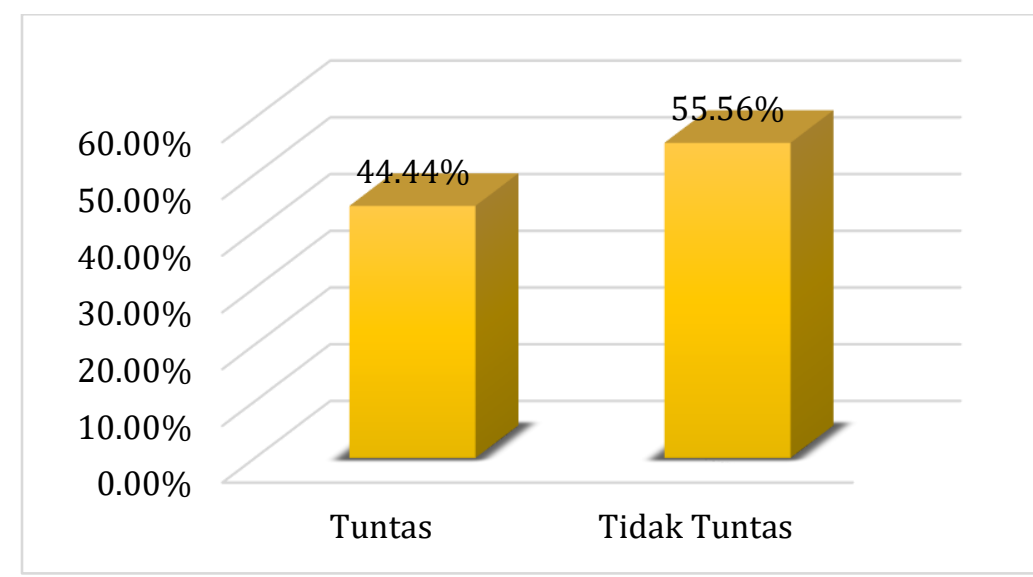

Gambar 3. Sebaran Ketuntasan Hasil Belajar Siswa Pada Akhir Siklus I.

\section{Aktivitas Belajar Siklus II.}

Hasil analisis siklus II menunjukkan aktivitas belajar siswa yakni pada Tabel 6.

Tabel 6. Data Aktivitas Belajar Siswa Siklus II

\begin{tabular}{lcccc}
\hline \multirow{1}{*}{ Kategori } & \multicolumn{4}{c}{ Sebaran Aktivitas Belajar Siswa } \\
& $\begin{array}{c}\text { Pertemuan Pertama } \\
\text { Jumlah }\end{array}$ & Persentase & $\begin{array}{c}\text { Pertemuan Kedua } \\
\text { Jumlah } \\
\text { Siswa }\end{array}$ & Presentase \\
& 6 & $13,33 \%$ & 12 & $26,67 \%$ \\
Sangat Aktif & 14 & $31,11 \%$ & 20 & $44,44 \%$ \\
Aktif & 18 & $40,00 \%$ & 13 & $28,89 \%$ \\
Cukup Aktif & 7 & $15,56 \%$ & 0 & $0,00 \%$ \\
Kurang Aktif & 0 & $0,00 \%$ & 0 & $0,00 \%$ \\
Sangat Kurang Aktif & 45 & $100,00 \%$ & 45 & $100,00 \%$ \\
\hline Jumlah & & & & \\
\hline
\end{tabular}

(Sumber: data diolah peneliti)

Berdasarkan tabel 6 diatas, jumlah siswa dengan kategori sangat aktif dan aktif meningkat secara signifikan daripada saat siklus I.

Berikut adalah bentuk grafik persentase aktivitas belajar dalam pertemuan I dan II selama siklus II. Persentase ini nampak pada gambar 4.

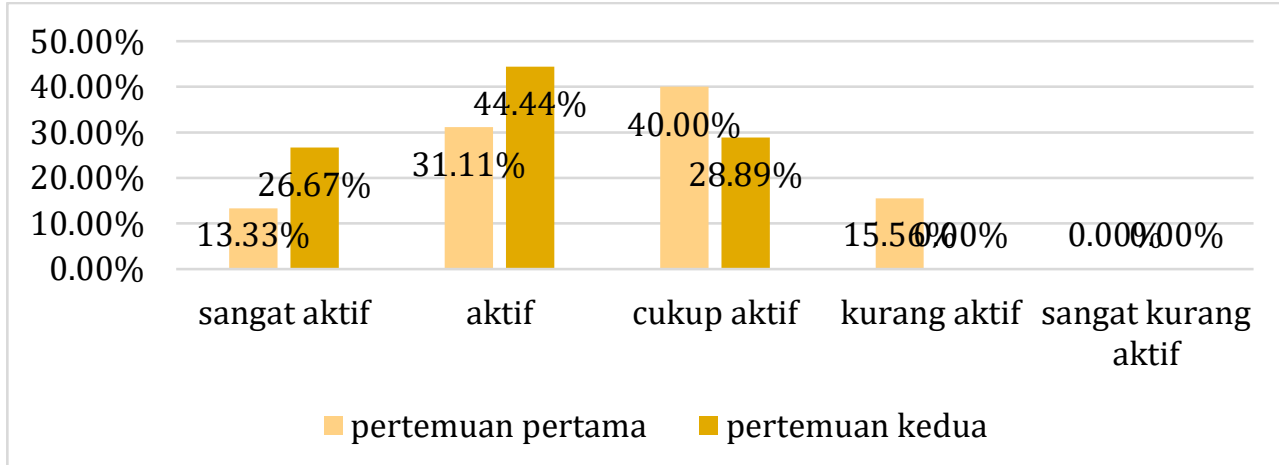

Gambar 4. Diagram Persentase Sebaran Aktivitas Belajar Siswa Siklus II.

Berdasarkan gambar diagram 4. ditunjukkan presentase sebaran aktivitas belajar siswa, dimana diketahui aktivitas belajar siswa di kategori sangat aktif dan aktif meningkat pesat di pertemuan kedua. Sedangkan pada kategori cukup aktif, kurang aktif maupun kategori sangat kurang aktif mengalami penurunan selama pertemuan kedua. 
Hasil Belajar Siklus II.

Dari hasil studi dan analisis siklus II, hasil belajar siswa siklus II ditunjukkan dalam Tabel 7.

Tabel 7. Data Hasil Belajar Siswa Siklus II

\begin{tabular}{|c|c|c|c|c|}
\hline No. & Rentangan Nilai & Kategori Nilai & Jumlah Siswa & Persentase \\
\hline 1. & $85-100$ & Sangat Baik & 13 & $28,89 \%$ \\
\hline 2. & $75-84$ & Baik & 20 & $44,44 \%$ \\
\hline 3. & $65-74$ & Cukup & 8 & $17,78 \%$ \\
\hline 4. & $41-64$ & Kurang & 4 & $8,89 \%$ \\
\hline 5. & $0-40$ & Sangat Kurang & 0 & $0,00 \%$ \\
\hline \multicolumn{3}{|c|}{ Total } & 45 & $100,00 \%$ \\
\hline
\end{tabular}

Sumber: (data diolah peneliti)

Tabel 7 diatas menunjukkan bahwa, jumlah siswa yang meraih kategori sesuai (KKM) yang sekolah tentukan telah meningkat secara signifikan.

Hasil belajar siswa berdasarkan (KKM) yakni 75, jadi bisa diamati jumlah siswa yang mencapai KKM di siklus II. Berikut adalah tabel tentang sebaran ketuntasan hasil belajar. Sebaran ketuntasan hasil belajar siswa siklus II ditunjukkan di Tabel 8.

Tabel 8. Sebaran Ketuntasan Frekuensi Hasil Belajar Siswa

\begin{tabular}{ccc}
\hline Keterangan & Jumlah Siswa & Presentase \\
\hline Tuntas & 33 & $73,33 \%$ \\
Tidak Tuntas & 12 & $26,67 \%$ \\
\hline Jumlah & 45 & $100,00 \%$ \\
\hline
\end{tabular}

Sumber: (data diolah).

Berdasarkan tabel diatas, ditunjukkan sebaran ketuntasan frekuensi hasil belajar siswa pada siklus II pada pembelajaran ekonomi. Jumlah siswa dengan nilai diatas KKM yaitu sejumlah 33 orang siswa, dengan besar presentase sebanyak $(73,33 \%)$ sedangkan terdapat 12 siswa dengan nilai dibawah KKM dengan besar presentase $(26,67 \%)$.

Berikut gambar grafik tentang sebaran ketuntasan belajar di akhir siklus II. Sebaran ketuntasan hasil belajar siswa ini nampak pada gambar 5 berikut.

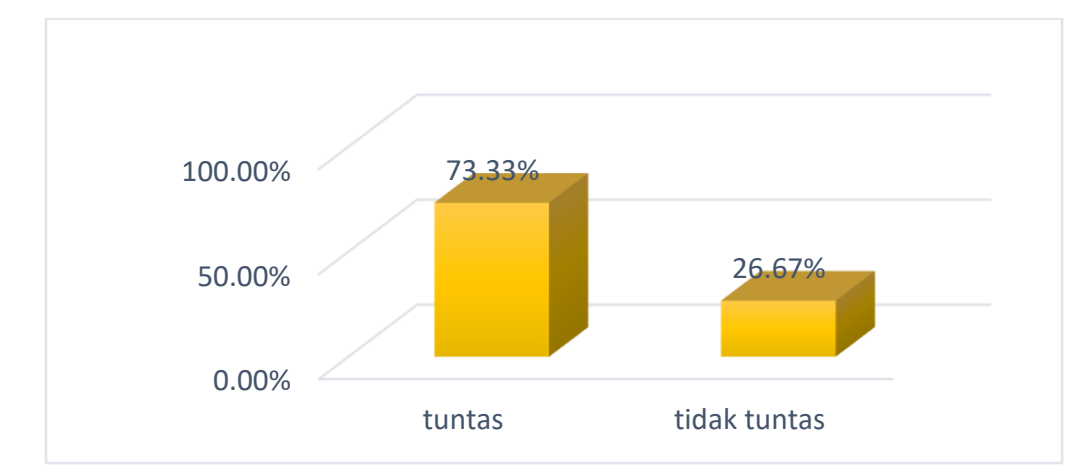

Gambar 5. Sebaran Ketuntasan Hasil Belajar Siswa Pada Akhir Siklus II.

\section{Pembahasan.}

Mengacu pada hasil studi diatas, pengimplementasian model kooperatif team assisted individualization (TAI) telah dilaksanakan pada dua siklus, serta meningkatkan aktivitas maupun hasil belajar siswa. Hal ini dibuktikan oleh adanya perkembangan aktivitas belajar yang dilaksanakan selama 2 minggu pada siklus I dan 2 minggu pada siklus II.

Saat dilakukan siklus I, rerata aktivitas belajar siswa sebanyak 6,75 yang menunjukkan aktivitas siswa berkategori cukup baik. Dalam hasil penelitian, jumlah siswa yang sangat aktif pada pembelajaran sejumlah 10 orang, sedangkan yang masih kurang aktif sebanyak 35 orang siswa. Dari data tersebut dapat dilihat siswa masih kurang aktif dalam mengikuti aktivitas belajar. Maka masih diperlukan untuk diadakan perbaikan nanti di siklus II. Saat pelaksanaan siklus II terjadinya peningkatan rerata aktivitas siswa 
sebanyak 8,85 yang menunjukkan kategori aktif pada aktivitas belajar siswa. Hasil pada siklus II membuktikan terdapat peningkatan jumlah siswa sangat aktif sebanyak 32 siswa, namun terdapat penurunan pada siswa yang kurang aktif sebanyak 13 orang. Data tersebut menunjukkan peningkatan aktivitas belajar siswa dengan pengimplementasian model pembelajaran TAI dikelas X IPA 4.

Hasil belajar siswa X IPA 4 SMA Negeri 2 Denpasar ketika pelaksanaan siklus I memperoleh rerata senilai 67,11. Hasil ini termasuk dalam kategori cukup. Jumlah siswa dengan nilai diatas Kriteria Ketuntasan Minimum (KKM) sejumlah 20 orang, sedangkan 25 orang memperoleh nilai dibawah KKM dengan ketuntasan belajar klasikal senilai 44,44\%. Dapat dikatakan masih banyak siswa dengan nilai kurang dari Kriteria Ketuntasan Minimun, maka masih diperlukan untuk diadakan perbaikan di siklus II. Saat siklus II terdapat peningkatan rerata hasil belajar siswa senilai 80,11 yang menunjukkan hasil belajar siswa masuk pada kategori baik. Hasil penelitian pada siklus II membuktikan adanya perubahan jumlah siswa dengan nilai diatas Kriteria Ketuntasan Minimum (KKM) sebanyak 33 orang siswa, sedangkan terdapat penurunan untuk siswa dengan nilai dibawah (KKM) yakni sebanyak 12 orang dimana belajar klasikal sebesar 73,33\%. Dari data tersebut menunjukkan peningkatan hasil belajar akibat penerapan model TAI di kelas X IPA 4.

Dari tercapainya aktivitas belajar dan hasil belajar yang telah dijelaskan diatas, hal ini mengakibatkan aktivitas maupun hasil belajar siswa meningkat dibandingkan siklus sebelumnya. Sistem pembagian kelompok secara heterogen, siswa belajar bersama dengan kelompok mereka saling bertukar pendapat tentang materi yang mereka dapatkan dimasing-masing individu, selain itu dapat berdiskusi dengan guru dalam proses pembelajaran dan pemberian nilai tambahan atau reward pada kelompok yang memperoleh nilai paling tinggi diakhir siklus. Darimenerapkan model pembelajaran TAI ini aktivitas belajar siswa dapat ditingkatkan.

Penentuan kelompok agar heterogen oleh guru ternyata mampu menciptakan situasi kerjasama dan diskusi kelompok yang lebih baik. Setiap siswa dengan kompetensi lebih dalam kelompok tersebut bisa membantu memaparkan materi yang tidak dimengerti oleh anggota tim dengan memiliki kemampuan yang masih kurang. Maka hal tersebut dapat membuat kerjasama dalam kelompok semakin erat dan saling membantu satu sam lain. Dengan pemberian reward atau nilai tambahan pada tim yang memperoleh nilai tertinggi diakhir siklus dapat memacu setiap siswa lebih aktif selama pembelajaran.

Hasil ini sejalan dengan teori dasar model pembelajaran TAI berdasarkan (Slavin, 2015) TAI adalah model pembelajaran yang mengkombinasikan belajar individual dengan kelompok, dan mengadakan kerja sama antar siswa dalam setiap tim dapat menyelesaikan masalah individual setiap kelompok serta saling menolong untuk berkembang sehingga guru dapat menghindari pengajaran langsung pada sebagian kecil siswa yang homogen.

\section{Simpulan dan saran Simpulan}

Menurut hasil studi dan pembahasan, adapun kesimpulan yang bisa dijabarkan yakni: model pembelajaran tipe team assisted individualization bisa meningkatkan aktivitas belajar siswa. Selama siklus I didapatkan rerata senilai 6,75 pada kategori cukup aktif, kemudian menjadi 8,85 dengan kategori aktif di siklus II, sedangkan model pembelajaran team assisted individualization (TAI) mampu meningkatkan pencapaian belajar siswa dengan rerata senilai 67,11 di siklus I dengan kategori cukup, kemudian meningkat hingga 80,11 dan berkategori baik di siklus II.

\section{Saran.}

Mengacu pada simpulan di atas, saran yang bisa disampaikan yakni: guru diharapkan mampu membangkitkan partisipasi siswa di kelas melalui pemanfaatan model ataupun metode pembelajaran yang tersedia, siswa diharapkan memahami bahwa materi pembelajaran tidaklah sekedar teori yang perlu dipelajari akan tetapi untuk diterapkan dalam aktivitas sehari-hari agar berguna bagi siswa, Penelitian ini dapat menjadi dasar untuk guru dalam memperbaiki proses belajar guna keberhasilan pencapaian siswa SMA Negeri 2 Denpasar melalui model pembelajaran TAI.

\section{Daftar Rujukan}

Ariani, T. (2017). Pembelajaran Kooperatif Tipe Team Assisted Individualization (TAI): Dampak Terhadap Hasil Belajar Fisika Siswa. Jurnal Ilmiah Pendidikan Fisika Al-Biruni, 6(2), 169.

Dimyati dan Mudjiono. (2015). Belajar dan Pembelajaran. Rineka cipta.

Hamalik, 0. (2015). Kurikulum dan Pembelajaran. Bumi Aksara.

Isjoni. (2019). Cooperative Learning, Efektivitas Pembelajaran Kelompok. Alfabeta.

Koyan. (2012). Statistik Pendidikan. Universitas Pendidikan Ganesha.

Nasution, S. (2017). Berbagai Pendekatan dalam Proses Belajar Mengajar. PT. Bumi Aksara.

Purwanto. (2017). Evaluasi Hasil Belajar. Pustaka Belajar. 
Sanjaya, W. (2014). Penelitian Tindakan Kelas. Kencana.

Sardiman, A. M. (2016). Interaksi dan Motivasi Belajar Mengajar. PT. Raja Grafindo Persada.

Sharan, S. (2014). The Handbook of Cooperative Learning: Inovasi Pengajaran dan Pembelajaran Untuk Memacu Keberhasilan Siswa Di Kelas. Grup Relasi Inti Media.

Slameto. (2015). Belajar dan Faktor-Faktor yang Menpengaruhinya. Pt. Rineka Cipta.

Slavin, R. E. (2015). Cooperative Learning, Teori, Riset, dan Praktek. Nusa Media.

Sudjana, N. (2016). Penilaian Hasil Proses Belajar Mengajar. Rosdikarya.

SUGIANTORO, A., \& ACHMADI HASYIM, B. (2019). Penerapan Model Pembelajaran Kooperatif Tipe Team Assisted Individualization Untuk Meningkatkan Hasil Belajar Siswa Pada Mata Pelajaran Teknologi Mekanik Kelas X Tpm Smk Negeri 2 Surabaya. Jurnal Pendidikan Teknik Mesin, 8(2), 136-141.

Suprijono, A. (2013). Cooperative Learning Teori dan Aplikasi PAIKEM. Pustaka Belajar.

Sutiari, N. L. (2019). Penerapan Model Pembelajaran Kooperatif Tipe Tai (Team Assisted Individualization) Untuk Meningkatkan Aktivitas Dan Prestasi Belajar Pada Mata Pelajaran Tata Graha. Jurnal Imiah Pendidikan Dan Pembelajaran, 3(1), 32.

Trianto. (2012). Pengantar Penelitian Pendidikan bagi Pengembangan Profesi dan Tenaga Kependidikan. Kencana.

Yuliantari, N. L. P. (2016). Implementasi Model Pembelajaran Kooperatif Tipe Tai ( Team Assisted Individualization ) Untuk Meningkatkan Aktivitas Dan Hasil Belajar Siswa Pada Mata Pelajaran Kewirausahaan Kelas X Smk N 1 Sukasada, Tahun Ajaran 2015 / 2016. Jurnal Prodi Pendidikan Ekonomi, 7(2), 3. 